\title{
Neotrinia gen. nov. and Pennatherum sect. nov. in Achnatherum (Poaceae: Stipeae)
}

\author{
M. Nobis ${ }^{1,2}$, P. D. Gudkova ${ }^{2,3}$, A. Nowak ${ }^{4}$ \\ ${ }^{1}$ Institute of Botany, Jagiellonian University, Gronostajowa 3, Kraków, 30-387, Poland.E-mail: m.nobis@uj.edu.pl \\ ${ }^{2}$ Institute of Biology, Tomsk State University, Lenin Prospect 36, Tomsk, 634050, Russian Federation. \\ E-mail:pdgudkova2017@yandex.ru \\ ${ }^{3}$ Biology faculty, Altai State University. Lenin Prospect 61, Barnaul, 656049, Russian Federation \\ ${ }^{4}$ Department of Biosystematics, Opole University, Oleska 48, Opole, PL-45-052,Poland.E-mail: anowak@uni.opole.pl
}

Keywords: new genus, new section, Poaceae, Stipeae, taxonomy.

Summary. Stipa splendens (syn. Achnatherum splendens) has been transferred to Neotrinia (Tzvelev) M. Nobis, P. Gudkova et A. Nowak gen. nov. as N. splendens (Trin.) M. Nobis, P. Gudkova et A. Nowak, based on a comparison of the macromorphology and lemma micromorphology of the Asian representatives of the tribe Stipeae. Lemma epidermal patterns in the examined species are presented and discussed. Additionally, a new section Pennatherum M. Nobis comprising Achnatherum pelliotii, a species recently transferred to Achnatherum from Ptilagrostis is also proposed. This taxon clearly differs from Ptilagrostis by the lemma micromorphology. The species with typical maizelike lemma micromorphological pattern is apparent member of Achnatherum, however, because of having plumose awns and short, blind calluses, it was earlier included into Ptilagrostis. Achnatherum pelliotii is the only Old Word Achnatherum species, with long pilose awns, thus, we propose to place it in the new section.

\section{Neotrinia gen. nov. и Pennatherum sect. nov. рода Achnatherum (Poaceae: Stipeae)}

\author{
М. Нобис ${ }^{1,2}$, П. Д. Гудкова ${ }^{2,3}$, А. Новак ${ }^{4}$ \\ ${ }^{1}$ Институт Ботаники, Ягеллонский университет, Горностаева, 3, г. Краков, 30-387, Польша \\ ${ }^{2}$ Биологический Институт, Томский государственный университет, пр. Ленина, 36, г. Томск, 634050, Россия \\ ${ }_{3}^{3}$ Биологический факультет, Алтайский государственный университет, пр. Ленина, 61, г. Барнаул, 656049, Россия \\ ${ }^{4}$ Факультет Биосистематики, Университет Ополе, Олеска, 48, г. Ополе, PL-45-052, Польша
}

Ключевые слова: новая секция, новый род, таксономия, Роасеае, Stipeae.

Аннотация. В статье приводится новый род Neotrinia (Tzvelev) M. Nobis, P. Gudkova et A. Nowak gen. nov., принадлежащий трибе Stipeae (Poaceae), включающий N. splendens (Trin.) M. Nobis, P. Gudkova et A. Nowak, (syn. Stipa splendens, Achnatherum splendens). Описание основано на сравнении макро- и микроморфологического строения нижних цветковых чешуй азиатских представителей трибы Stipeae. Также представлено обсуждение паттернов микроморфологического строения нижних цветковых чешуй исследованных (азиатских) видов трибы Stipeae. Кроме того, описана новая секция Pennatherum M. Nobis рода Achnatherum, включающая A. pelliotii, вид, недавно переведенный в Achnatherum из близкородственного рода Ptilagrostis. Achnatherum pelliotii отличается от Ptilagrostis по микроморфологическому строению нижних цветковых чешуй и относит- 
ся к типичному «maize-like» паттерну; этот вид является явным представителем рода Achnatherum, однако изза наличия перистых остей и короткого тупого каллуса он был ранее отнесен к роду Ptilagrostis. В настоящее время A. pelliotii - единственный вид Achnatherum из Старого света с опушенными остями, поэтому данный вид был отнесен к новой секции.

The number of genera recognized within the tribe Stipeae Dumort. (Poaceae) and their treatment have varied considerably over the years (Roshevitz, 1916, 1934; Tzvelev, 1976; Wu, Phillips, 2006; Barkworth, 2007; Hamasha et al., 2012; Romaschenko et al., 2012; Nobis, 2013). This is particularly noticeable in the genus Stipa L., which some authors has interpreted as including almost all members of the tribe with elongated florets (e.g., Steudel, 1854; Hitchcock, 1951; Bor, 1970; Freitag, 1985), but which most of researchers currently studying the tribe treat as an Old World genus with around 150 species (Hamasha et al., 2012; Nobis, 2013, 2014). Similarly is in the case of Achnatherum P.Beauv., which is treated as separate genus, comprising species occurring in the Old and the New World (Tzvelev, 1976; Romaschenko et al., 2012). Recently, based on molecular evidence, some species have been separated from Achnatherum and transferred to such genera like Stipellula M. Röser et H. R. Hamasha, Aristella (Trin.) Bertol. and $\mathrm{Pa}$ tis Ohwi (Hamasha et al., 2012; Romaschenko et al., 2014). However, the placement of some species within these above mentioned genera requires further studies (Nobis et al., unpbl).

Achnatherum is a genus comprising approximately 56 widely distributed taxa, of which 35 occur in Eurasia and Africa, 25 in Americas and one in New Zealand (Tzvelev, 1976; Romaschenko et al., 2012). Achnatherum is regarded as polyphyletic genus, split into few clades (Hamasha et al., 2012; Romaschenko et al., 2012), that slightly differ in both morphology and molecular traits. Nevertheless, all species representing the genus are clearly distinguishable by the lemma micromorphological patterns, which are considered as conservative and important phylogenetic character (Tzvelev, 1977; Barkworth et al., 1987; Romaschenko et al., 2012; Nobis, Nobis, 2013; Nobis et al., 2014, 2015). Members of the genus Achnatherum have typical maize-like pattern of the lemma micromorphology (Romaschenko et al., 2012), with very frequent silica bodies and short fundamental cells (Fig. 1). Based on molecular studies, Achnatherum pelliotii (Danguy) M. Röser et H. R. Hamasha has been transferred from the genus Ptilagrostis (Hamasha et al., 2012). This taxon clearly differs from all the members of the genus Ptilagrostis by the lemma micromorphology. The species with typical maizelike lemma micromorphological pattern is apparent member of Achnatherum (Fig. 1), however, because of the presence of plumose awns and short, blind calluses, it was earlier included in Ptilagrostis. Currently, Achnatherum pelliotii is the only Old Word Achnatherum species, with long pilose awns, thus, we propose to place it in the new section Pennatherum (see below).

A similar problem applies to Achnatherum splendens (Trin.) Nevski [= Stipa splendens Trin.]. This species also distinctly differs from Achnatherum and Stipa species both by molecular traits (Hamasha et al., 2012; Romaschenko et al., 2012) and the lemma micromorphology (Fig. 1). In phylogenetic studies on the tribe Stipeae (Hamasha et al., 2012; Romaschenko et al., 2012, 2014), the species is located outside of Eurasian and American clades comprising Achnatherum, Stipa, Ptilagrostis and Trikeraia. Stipa splendens was described from Transbaikal region in the Central Asia, however, based on its morphology it was transferred by Knuth (1829) to Lasiagrostis Link, and later by Nevskyi (1937) to Achnatherum. The placement of this species in Achnatherum was later confirmed and established by Pazij (1968), Tzvelev $(1972,1976)$, Lomonosova (1990), Wu and Phillips (2006), however, rejected and treated in traditional concept as Stipa splendens by Bor (1960, 1970), Cope (1982) and Freitag (1985). Achnatherum splendens has a broad distribution. It occurs in southern Russia, Mongolia, China, Japan, Kazakhstan, Kyrgyzstan, Tajikistan, Uzbekistan, Turkmenistan, Afghanistan, Iran, Pakistan, India (Bor, 1968, 1970; Pazij, 1968; Tzvelev, 1976; Freitag, 1985; Wu, Phillips, 2006). It is very well distinguishable species, forming dense (large and wide) tufts with high and hard stems, with long, hard and rigid leaves, long and dense panicles with numerous flowers. On the basis of these characters, the discussed species does not resemble any of the remaining species of Achnatherum. Moreover, the lemma epidermal pattern of $A$. splendens is somewhat similar to those having by the members of Ptilagrostis, Trickeraia, Orthoraphium and Psammochloa, rather than Achnatherum and Stipa (Fig. 1; Romaschenko et al., 2012; Nobis, 2013, 2014; 

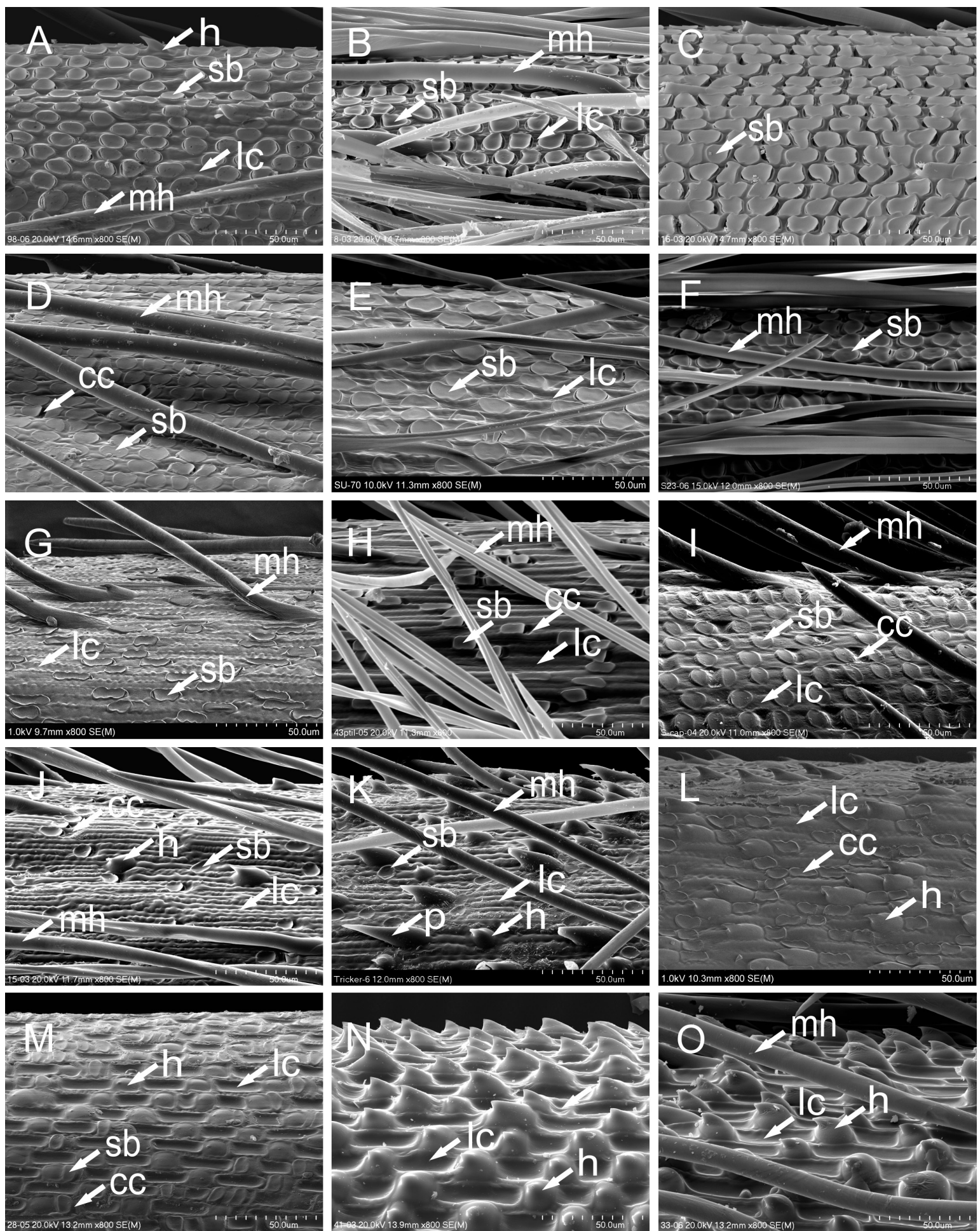

Fig. 1. SEM morphology of lemma epidermal patterns of: A - Achnatherum calamagrostis (L.) Beauv., France, 24 Jul 1964, S. and B. Pawłowscy (KRA122557); B - A. pelliotii (Danguy) M. Röser et H.R. Hamasha, China, 31 May 1957, A.A. Yuantov et al. (LE); C - A. turkomanicum (Roshev.) Tzvelev, Kyrgyzstan, 2 Jul 2015, M. Nobis, A. Nowak (KRA); D - A. brandisii (Mez) Z. L. Wu, India, 8 Aug 1939, R. R. Stewart 18120 (NY); E - A. inebrians (Hance) Keng, China, 08 Jul 1873, N. M. Przewalski (LE); F - A. caragana (Trin.) Nevski, Tajikistan, 10 Jun 2012, M. Nobis, A. Nowak (KRA); G - Ptilagrostis alpina (Fr. Schmidt) Sipl., Russia, 10 Aug 1978, S. Kharkevich, T. Bush (NY); H P. malyschevii Tzvelev, Kyrgyzstan, 8 Aug 1956, L. I. Popova, A. Noldoyarov (FRU); I - Stipellula capensis (Thunb.) M. Röser et H.R. Hamasha, Spain, May 2009, R. Piwowarczyk (KRA); J, K - Neotrinia splendens (Trin.) M. Nobis, P. Gudkova et A. Nowak, Tajikistan, 30 Jul 1958, Yu. Gusev (LE), China, Quighai, 26 Jul 2010, B. Paszko (KRA); L Orthoraphium roylei Nees, Nepal, 22 Oct 1981, M. A. Farille (E); M - Stipa grandis P.A. Smirn., Mongolia, 50 km SW of Choibalsan, 19 Aug 2011, Safronova et al. (KRA); N - S. bungeana Trin., Kyrgyzstan, 08 Jul 2015, M. Nobis, A. Nowak (KRA); O - S. lessingiana Trin. et Rupr., Kazakhstan, 18 May 2014, M. Nobis (KRA). Abbreviations: lc long cell (fundamental cell), sc - silica cell (silica body), cc - cork cell, h - hook, p - pricle, mh - macrohair. 
Nobis et al., 2013, 2014, 2015, 2016). In A. splendens, the fundamental (long) cells are elongate with deeply sinuous side walls; silica bodies are rounded, square to elongated with straight or sinuous edges; cork cells are adjacent to silica bodies; hooks, prickles and macrohairs are sparse and scattered on the whole lemma surface (Fig. 1J-K). Because molecular, macromorphological and micromorphological characters do not support its affiliation to Achnatherum as well as to any other related genera from the tribe Stipeae, the following transfer is necessary:

Neotrinia (Tzvelev) M. Nobis, P. Gudkova et A. Nowak, stat. et gen. nov.

Basionym: Achnatherum sect. Neotrinia Tzvelev, Nov. Syst. Vyssh. Rast. 9: 55, 1972.

Type: Neotrinia splendens (Trin.) M. Nobis, P. Gudkova et A. Nowak

Neotrinia splendens (Trin.) M. Nobis, P. Gudkova et A. Nowak, comb. nov.

Basionym: Stipa splendens Trinius in Sprengel, Neue Entdeck. Pflanzenk., 2: 54, 1821.

Type: (USSR, Transbaikalia) Agrostis longiaristata, herb. Fischer (holotype LE!).

Based on the same type: Lasiagrostis splendens (Trin.) Knuth (1829, p. 58); Achnatherum splendens (Trin.) Nevski (1937, p. 224).

Taxonomic synonym: Stipa altaica Trin. (1929, p. 80); Stipa schlagintweitii Mez (1921, p. 208); Sti- pa kokonorica Hao (1938, p. 583); Stipa munroana Bor (1955, p. 500).

\section{A new section in the genus Achnatherum}

Achnatherum sect. Pennatherum M. Nobis, sect. nov.

Description: Perennial, densely tufted from a short rhizome, old basal sheaths persistent. Leaf blades gray-green, fairly rigid, setaceous; ligules truncate, ca. $1 \mathrm{~mm}$, margin ciliate. Panicle lax. Glumes lanceolate, 5-6 mm, 3-veined with lateral veins short, membranous, smooth, apex sharply acuminate; lemma 3-4 mm, 3-veined, veins convergent at apex, evenly pubescent throughout, apex minutely 2-toothed; awn $2-3 \mathrm{~cm}$, strongly curved near base, column short, twisted, plumose; palea subequal to lemma.

Type: Achnatherum pelliotii (Danguy) Röser et H. R. Hamasha, Plant. Syst. Evol., 298: 365, 2012.

Acknowledgments. We would like to express our gratitude to the curators of B, E, FRU, GOET, KHOR, KRA, KUN, LE, M, NY, MSB, MW, P, PE, PR, TAD, TK, UPS, W, WA, WU for making the collections of the tribe Stipeae available for study. The research was funded by the National Science Centre, Poland based on the decision no. 2013/09/B/ NZ8/03287 as well as Russian Foundation for Basic Research no. 18-34-20112 mol_a_ved.

\section{REFERENCES / ЛИTEPATУPA}

Barkworth M. E. 2007. Stipeae Dumort. In: Flora of North America, North of Mexico. Vol. 24. Oxford Univ. Press, 109-111 pp.

Barkworth M. E., Everett J. 1987. Evolution in the Stipeae: identification and relationships of its monophyletic taxa. In: Grass systematics and evolution. Smithsonian Institution, Washington, D. C., 251-264 pp.

Bor N. L. 1960. Grasses of Burma, Ceylon, India and Pakistan (excluding Bambuseae). Pergamon Press, London, $767 \mathrm{pp}$.

Bor N. L. 1970. Gramineae. In: Flora Iranica. Vol. 70. Academisch Druck-u. Verlagsanstalt, Graz - Austria, 1-573 pp. +72 tabl.

Cope T. A. 1982. Poaceae. In: Flora of Pakistan. № 143. University of Karachi, Karachi, 678 pp.

Freitag H. 1985. The genus Stipa (Gramineae) in southwest and south Asia. Notes R. Bot. Gard. Edinb. 42: 355-489.

Hamasha H. R., von Hagen K. B., Röser M. 2012. Stipa (Poaceae) and allies in the Old World: molecular phylogenetics realigns genus circumscription and gives evidence on the origin of American and Australian lineages. Plant Syst. Evol. 298: 351-367.

Hitchcock A. S. 1950. Manual of the grasses of the United States, 2nd ed. Misc. Publ. USDA, no. 200, Washington, $1051 \mathrm{pp}$.

Kunth C. S. 1829. Révision des graminées publiées dans les Nova genera et species plantarum de Humboldt et Bonpland; précédée d'un travail général sur la famille des graminées 1. Gide fils, Paris. 374 pp.

Lomonosova M. N. 1990. Achnatherum Beauv. In: Flora Sibiri [Flora of Siberia]. Vol. 2. Nauka, Novosibirsk, 220-221 pp. [In Russian]. (Ломоносова М. Н. Achnatherum Beauv. // Флора Сибири. Т. 2. Новосибирск: Наука, 1990. C. 220-221).

Martinovský J. O. 1980. Stipa L. In: Flora Europaea. Vol. 5. Cambridge Univ. Press, 247-252 pp. 
Nevski S. A. 1937. Materialy k flore Kugitanga i ego predgorii. Trudy botanicheskogo instituta Akademii nauk SSSR. Ser. 1. Flora i sistematika vysshikh rasteniy 4: 199-346 [In Russian]. (Невский С. А. Материалы к флоре Кугитанга и его предгорий // Труды ботанического института Академии наук СССР. Сер. 1. Флора и систематика высших растений, 1937. № 4. С. 199-346).

Nobis M. 2013. Taxonomic revision of the Stipa lipskyi group (Poaceae: Stipa section Smirnovia) in the Pamir Alai and Tian-Shan Mountains. Plant Syst. Evol. 299: 1307-1354

Nobis M. 2014. Taxonomic revision of the Central Asiatic Stipa tianschanica complex (Poaceae) with particular reference to the epidermal micromorphology of the lemma. Folia Geobot. 49: 283-308.

Nobis M., Nowak A., Nobis A. 2013. Stipa zeravshanica sp. nov. (Poaceae), an endemic species from rocky walls of the western Pamir Alai Mountains (middle Asia). Nordic J. Bot. 31: 666-675.

Nobis M., Nobis A., Nowak A., Nowak S. 2014. Stipa klimesii (Poaceae), a new species from Western Himalayas (India). Phytotaxa 174(3): 173-180.

Nobis M., Nowak A., Gudkova P. D. 2015. A new synonym and a new combination in Stipa aliena Keng (Poaceae: Stipa sect. Regelia). Phytotaxa 195(3): 236-242.

Nobis M., Klichowska E., Nowak A., Gudkova P. D., Rola K. 2016. Multivariate morphometric analysis of the Stipa turkestanica group (Poaceae: Stipa sect. Stipa). Plant Syst. Evol. 302(2): 137-153.

Nobis M., Nobis A. 2013. Ptilagrostis milleri comb. nov. (Poaceae: Stipeae). Nordic J. Bot. 31: 623-625.

Pazij V. K. 1968. Stipa L. In: Opredelitel rastieniy Sredniey Azii (Conspectus florae Asiae Mediae) [Key to vegetation of Central Asia (Checklist of flora Meddle Asia)]. Vol. 1. Publ. Fan, Tashkent, 64-82, 200-201 pp. [In Russian]. (Пазий B. K. Stipa L. // Определитель растений Средней Азии (Конспект флоры Средней Азии). T. 1. Ташкент: Изд-во «Фан», 1968. С. 64-82, 200-201).

Romaschenko K., Garcia-Jacas N., Peterson P. M., Soreng R. J., Vilatersana R., Susanna A.

2014. Miocene-Pliocene speciation, introgression, and migration of Patis and Ptilagrostis (Poaceae: Stipeae). Mol. Phyl. Evol. 70: 244-259.

Romaschenko K., Peterson P. M., Soreng R. J., Garcia-Jacas N., Futorna O., A. Susanna. 2012. Systematics and evolution of the needle grasses (Poaceae: Pooideae: Stipeae) based on analysis of multiple chloroplast loci, ITS, and lemma micromorphology. Taxon 61: 18-44.

Roshevitz, R. Yu. 1916. Zlaki (Gramineae). In: Flora Aziatskoy Rossii [Flora of Asian Russia]. Vol. 3, iss. 12. Peresel. Upravl. Minist. Zemled., Petrograd, 191 pp. [In Russian]. (Рожевиц Р. Ю. Злаки // Флора Азиатской России. Т. 3, вып. 12. Петроград: Пересел. Управл. Минист. Землед., 1916. 191 с.).

Roshevitz R. Yu. 1934. Stipa L. In: Flora SSSR [Flora of the USSR]. Vol. 2. Academiae Scientiarum URSS, Leningrad, 79-112, 740-741 pp. [In Russian]. (Рожевиц P. Ю. Stipa L. // Флора СССР. Т. 2. Л.: АН СССР, 1934. C. 79-112, 740-741).

Steudel E. G. 1854. Synopsis plantarum glumacearum. 1. Stuttgart, 475 pp.

Tzvelev N. N. 1972. Taxa nova Poacearum florae URSS. Novosti sistematiki vysshikh rasteniy [Novit. Syst. Pl. Vasc.] 9: 55-63 [In Russian]. (Цвелев Н. Н. Новые таксоны Роасеае флоры СССР // Новости сист. высш. раст., 1972. 9: 55-63).

Tzvelev N. N. 1976. Zlaki SSSR [Grasses of the USSR]. Nauka, Moscow, 788 pp. [In Russian]. (Цвелев Н. Н. Злаки СССР. М.: Наука, 1976. 788 с.)

Tzvelev N. N. 1977. About the origin and evolution of feather grasses. In: Problemy ekologii, geobotaniki, botanicheskoy geografii i floristiki [Problems of ecology, geobotany, botanical geography and floristics]. Nauka, Leningrad, 139-150 pp. [In Russian]. (Цвелев Н. Н. О происхождении и эволюции ковылей (Stipa L.) // Проблемы экологии, геоботаники, ботанической географии и флористики, 1977. С. 139-150).

Wu Z. L., Phillips S. M. 2006. Tribe Stipae. In: Flora of China. Vol. 22. Science Press, Miss. Bot. Gard. Press, $188-212 \mathrm{pp}$. 